\title{
Correlation between Serum vitamin D and Asthma Control in Asthmatic Children
}

\author{
R.S.Arafa ${ }^{1}$, Y.M.Ismail ${ }^{2}$, A.A.Sobeih ${ }^{1}$, R.M.Zakaria ${ }^{1}$ and Sh.A.Abd El Mordy ${ }^{1}$ \\ ${ }^{1}$ Pediatrics Dept, Faculty of Medicine, Benha Univ., Benha, Egypt \\ ${ }^{2}$ clinical pathology Dept, Faculty of Medicine, Benha Univ., Egypt \\ E-Mail:drshimaazakzouk@yahoo.com
}

\begin{abstract}
Asthma is a chronic ,inflammatory, respiratory tract disease accompanied by hypersensitivity of airways, recurring wheezing episodes, respiratory distress and coughing. The aim of this study was to estimate vitamin D level and specific IgE level in asthmatic children who were on controller medication and correlated their serum level with asthma control . Our results clarified that The serum vitamin[D] levels were closely related to asthma attacks. As, There were statistically significant positive correlations between serum vitamin D level and asthma control in asthmatic children. There were no significant difference in mean serum vitamin [D] between male and female and according to parent consanguinity while shows significant difference regarding order of sibling. there were no significant difference in mean serum vitamin [D] according to family history of atopy and passive smoking, while shows significant difference regarding family history of asthma, associated allergic condition, day time symptoms, night time awakness, degree of asthma control, recurrent hospital admission , interference with activity and frequency of exacerbation and influenza \&pneumococcal vaccination. significant difference in mean serum vitamin [D] according to food born allergen: apple ,banana ,casein ,cow milk ,egg white, peanut while regarding airborne allergen shows nonsignificant difference with ,Der.pteronyssinus, Der.farinae ,Cockroach and Honey bee venom and Aspergillus fumigatus . Common wasp venom, Altearia alternate, Honey bee venum,Birch ,Candida albican ,Dog epith. and cat epithelium demonstrated significant difference. From our results, it would be concluded that there was a significant correlation between vitamin [D] level and asthma control in asthmatic children .
\end{abstract}

Keywords: Childhood asthma, Vitamin [D], Specific IgE.

\section{Introduction}

Asthma in children has become a public health problem, various epidemiological studies have shown that the global prevalence of asthma in children ranges from 3 to $29 \%$ [1].

The occurrence of asthma in children can be caused by many factors, environmental, gender, genetic, ethnic factors and socioeconomic status [2]. In recent years, studies have shown that vitamin D levels and the incidence of asthma were closely related. Several clinical trials have tested whether taking Vitamin D as a supplement has an effect on asthma attacks, symptoms and lung function in children and adults with asthma. Vitamin D supplementation can regulate the body's immune function, reduce inflammation and initiate repair functions in the body [3].

VitD may play a role in reducing the risk for respiratory infections, [4] a major trigger factor for asthma[5],viral infections are a known primary risk factor in the onset of asthma attack. During a viral infection, vitamin $\mathrm{D}$ is responsible for the production of cathelicidinin, an antimicrobial polypeptide. Research exhibits vitamin D supplements reduce upper respiratory tract infection significantly [6].Low levels of vitamin D may reduce the efficacy of steroid action in asthmatics resulting in poor symptoms control [7].The aim of this study was to estmate vitamin D level and Specific IgE in asthmatic childern and correlated their serum with asthma control.

\section{Materials and methods}

This was a cross-sectional study which included 60 children aged from 4 years up to 15 year diagnosed as bronchial asthma attending pediatric chest and asthma clinic, Benha university Hospitals .

\subsection{Inclusion criteria}

- The patients presenting with clinical manifestations of cough, chest tightness, lung wheezing, night and/or early morning onset or exacerbate.

- Patients who meet the asthma diagnostic criteria according to GINA guidelines 2017

- Childern aged 4 years up to 15 year.

- Asthmatic children on asthma controller drugs e.g [inhaled steroid, leuktriens].

- Informed consent will be obtained from parents.

\subsection{Exclusion criteria}

- Any chest problem other than asthma e.g pneumonia and cystic fibrosis.

- Age < 4years or $>15$ year 
- Any chronic systemic illness e.g Heart,liver, kidney and CNS diseases.

- Children who are on hormonal drugs during the previous 30 days.

- Children who were on Vitamin D therapy during the previous 30 days.

\section{Methods}

3.1 Every child was subjected to the following:

\section{1- Full History taking}

Personal history [name, age, sex, residence and school attendance], History of the present illness: Symptoms related to asthma, [wheezing, dyspnea, cough, fatigue and cyanosis, Onset and duration of asthma, frequency of attacks, and seasonal variation. Other atopic complaints as rhinitis, eczema, urticaria and Conjunctivitis. History of treatment: number of times of hospitalization due to asthma, treatment during acute attack, prophylactic treatment. Family history of similar condition, atopy, asthma, allergic rhinitis, urticaria and Conjunctivitis. Smoking history. Controller medication like inhaled corticosteroids [ICS] and leukotrienes.

\section{2- full clinical examination}

General examination and local examination: Chest examination :Inspection, Palpation, Percussion, Auscultation .

CNS examination, Abdominal examination and Cardiovascular system examination.

\section{3- Pulmonary function tests}

peak expiratory flow rate [PEFR].

\section{4- Lab. Investigation}

Serum level of vitamin D [25-Hydroxyl D3]was estimated using vidas [Vitek ImmunoDiagnostic Assay System],Serum level of specific IGE was estimated by The AllergyScreen and the AlleisaScreen .

\subsection{Sample collection}

serum or plasma[lithium heparin] from $10 \mathrm{~cm}$ blood sample under complete aseptic technique, using plastic tube with lithium heparin and separation gel.

Serum and plasma samples was stored in primary tube at $18-25 \mathrm{c}$ for up to 8 hours or aliquoted at 2-8c for up to 5 days.

For these serum sample ensured that complete clot formation has taken place prior to centrifugation as insufficient clot result information of fibrin with micro-clots lead to erroneous results.

\subsection{Statistical data management}

\subsection{Data management}

The clinical data were recorded on a report form. These data were tabulated and analysed using the computer program SPSS [Statistical package for social science] version 20 to obtain.

\subsection{Descriptive data}

Descriptive statistics were calculated for the data in the form of

1-Mean and standard deviation $( \pm S D)$.

Median and inter-quartile range [IQR] for quantitative data.

2-Frequency and distribution for qualitative data.

\subsection{Analytical statistics}

In the statistical comparison between the different groups, the significance of difference was tested using one of the following tests:-

1- Student's $t$-test:- Used to compare mean of two groups of quantitative data.

2- ANOVA test [F value]:-Used to compare mean of more than two groups of quantitative data.

A $P$ value $<0.05$ was considered statistically significant [*] while $>0.05$ statistically insignificant $\mathrm{P}$ value $<0.01$ was considered highly significant $[* *]$ in all analyses.

\section{Results}

There were non-significant difference in mean serum vit. [D] between male and female and according to parent consanguinity while shows significant difference regarding order of sibling[ $\mathrm{p}<0,05]$ Table (1).

There were non significant difference in mean serum vit. [D] according to family history of atopy and passive smoking, while shows significant difference regarding family history of asthma,associated allergic condition, day time symptoms,night time awakness, degree of asthma control, recurrent hospital admission and interference with activity Table (2)

There were significant difference in mean serum vit. [D] according to frequency of exacerbation and influenza \&pneumococcal vaccination Table (3).

There were significant difference in mean serum vitamin [D] according to food born allergen: apple ,banana ,casein ,cow milk ,egg white, peanut while regarding airborne shows nonsignificant difference with ,Der.pteronyssinus,Cockroach and Der.farinae Honey bee venom and Aspergillus fumigatus . Common wasp venom, Alternaria alternate, Honey bee venum,Birch ,Candida albican ,Dog 
epith. and cat epithelium demonstrated significant difference Table (4).

Table (1) Serum vit D differences according to sex,order of sibling and parent consanguinity.

\begin{tabular}{|c|c|c|c|c|c|}
\hline & No & mean & \pm SD & $\begin{array}{c}\text { Statistical } \\
\text { test }\end{array}$ & $P$ value \\
\hline \multicolumn{6}{|c|}{ Serum vit D } \\
\hline \multicolumn{6}{|c|}{$\operatorname{Sex}$} \\
\hline \multirow[t]{2}{*}{ Male } & 30 & 12.91 & 7.02 & St $t=0.35$ & 0.73 \\
\hline & 30 & 13.44 & 4.52 & & \\
\hline \multicolumn{6}{|c|}{ Female } \\
\hline \multicolumn{6}{|c|}{ Order in his sibling } \\
\hline $1^{\text {st }}$ & 24 & 15.4 & 7.03 & $\mathrm{~F}=11.35$ & $<0.001 * *$ \\
\hline $2^{\text {nd }}$ & 24 & 14.42 & 2.33 & & \\
\hline $3^{\text {rd }}$ & 6 & 7.93ab & 0.0 & & \\
\hline $4^{\text {th }}$ & 6 & $4.56 \mathrm{ab}$ & 0.0 & & \\
\hline \multicolumn{6}{|c|}{ Parent consanguinity } \\
\hline Yes & 24 & 13.34 & 5.85 & St $\mathrm{t}=0.18$ & 0.86 \\
\hline No & 36 & 13.07 & 5.95 & & \\
\hline
\end{tabular}

Table (2) Serum vit D differences

\begin{tabular}{|c|c|c|c|c|c|}
\hline Serum vit D & No & mean & \pm SD & $\begin{array}{c}\text { Statistical } \\
\text { test }\end{array}$ & $P$ value \\
\hline $\begin{array}{l}\text { Family history of atopy } \\
\text { Yes } \\
\text { No } \\
\end{array}$ & $\begin{array}{l}42 \\
18 \\
\end{array}$ & $\begin{array}{l}13.12 \\
13.31 \\
\end{array}$ & $\begin{array}{c}6.46 \\
4.3 \\
\end{array}$ & St $\mathrm{t}=0.12$ & 0.91 \\
\hline $\begin{array}{l}\text { Family history of asthma } \\
\text { Yes } \\
\text { No } \\
\end{array}$ & $\begin{array}{l}24 \\
36 \\
\end{array}$ & $\begin{array}{c}16.89 \\
10.7 \\
\end{array}$ & $\begin{array}{c}6.8 \\
3.43 \\
\end{array}$ & St $\mathrm{t}=4.66$ & $<0.001 * *$ \\
\hline $\begin{array}{l}\text { Associated allergic condition } \\
\text { Yes } \\
\text { No } \\
\end{array}$ & $\begin{array}{l}18 \\
42 \\
\end{array}$ & $\begin{array}{l}15.71 \\
12.09 \\
\end{array}$ & $\begin{array}{l}4.25 \\
6.16 \\
\end{array}$ & St $\mathrm{t}=2.27$ & $0.027 *$ \\
\hline $\begin{array}{l}\text { Passive smoking } \\
\text { Yes } \\
\text { No } \\
\end{array}$ & $\begin{array}{c}54 \\
6 \\
\end{array}$ & $\begin{array}{c}13.11 \\
13.8 \\
\end{array}$ & $\begin{array}{c}6.18 \\
0.0 \\
\end{array}$ & St $\mathrm{t}=0.27$ & 0.79 \\
\hline $\begin{array}{l}\text { Day time symptoms } \\
<2 / \mathrm{w} \\
>2 / \mathrm{w} \\
\text { Daily }\end{array}$ & $\begin{array}{l}18 \\
18 \\
24\end{array}$ & $\begin{array}{c}12.61 \\
17.23 \mathrm{a} \\
10.56 \mathrm{~b}\end{array}$ & $\begin{array}{l}0.87 \\
6.77 \\
5.78 \\
\end{array}$ & $\mathrm{~F}=8.49$ & $0.001 * *$ \\
\hline $\begin{array}{l}\text { Night time awakness } \\
<2 / \mathrm{m} \\
>2 / \mathrm{m} \\
>1 / \mathrm{w}\end{array}$ & $\begin{array}{l}18 \\
18 \\
24 \\
\end{array}$ & $\begin{array}{c}12.61 \\
17.23 \mathrm{a} \\
10.56 \mathrm{~b} \\
\end{array}$ & $\begin{array}{l}0.87 \\
6.77 \\
5.78 \\
\end{array}$ & $\mathrm{~F}=8.49$ & $0.001 * *$ \\
\hline $\begin{array}{l}\text { Degree of control } \\
\text { Good } \\
\text { Fair } \\
\text { Poor }\end{array}$ & $\begin{array}{l}18 \\
18 \\
24 \\
\end{array}$ & $\begin{array}{c}12.61 \\
17.23 \mathrm{a} \\
10.56 \mathrm{~b}\end{array}$ & $\begin{array}{l}0.87 \\
6.77 \\
5.78 \\
\end{array}$ & $\mathrm{~F}=8.49$ & $0.001 * *$ \\
\hline $\begin{array}{l}\text { Recurrent hosp admission } \\
\text { Once } \\
\text { Twice } \\
\text { Yes } \\
\text { No } \\
\end{array}$ & $\begin{array}{c}6 \\
6 \\
36 \\
12 \\
\end{array}$ & $\begin{array}{c}22.3 \\
11.88 \mathrm{a} \\
11.94 \mathrm{a} \\
12.98 \mathrm{a} \\
\end{array}$ & $\begin{array}{c}0.0 \\
0.0 \\
6.44 \\
0.86 \\
\end{array}$ & $\mathrm{~F}=7.22$ & $<0.001 * *$ \\
\hline $\begin{array}{l}\text { Interference with activity } \\
\text { Yes } \\
\text { Minor } \\
\text { No } \\
\end{array}$ & $\begin{array}{l}24 \\
12 \\
24 \\
\end{array}$ & $\begin{array}{l}10.56 \\
15.12 \\
14.82 \\
\end{array}$ & $\begin{array}{c}5.78 \\
7.5 \\
3.98 \\
\end{array}$ & $\mathrm{~F}=4.46$ & $0.016^{*}$ \\
\hline
\end{tabular}


Table(3) Serum vit D differences according to frequency of exacerbation and influenza.

\begin{tabular}{|c|c|c|c|c|c|}
\hline Serum vit D & No & mean & \pm SD & $\begin{array}{c}\text { Statistical } \\
\text { test }\end{array}$ & $P$ value \\
\hline \multicolumn{6}{|c|}{ Frequency of exacerbation } \\
\hline $0-1 /$ year & 18 & 12.61 & 0.87 & $F=9.15$ & $<0.001 * *$ \\
\hline$<2 /$ year & 12 & 15.12 & 7.5 & & \\
\hline$>1 /$ year & 6 & $21.45 \mathrm{ab}$ & 0.0 & & \\
\hline$>2 /$ year & 12 & $11.91 \mathrm{c}$ & 6.5 & & \\
\hline$>1 /$ month & 6 & $4.56 \mathrm{abcd}$ & 0.0 & & \\
\hline Frequent & 6 & $13.88 \mathrm{ce}$ & 0.0 & & \\
\hline \multicolumn{6}{|c|}{ Influenza \&pneumococcal } \\
\hline Yes & 48 & 12.27 & 5.78 & $\mathrm{St} \mathrm{t}=2.5$ & $0.015^{*}$ \\
\hline No & 12 & 16.81 & 4.85 & & \\
\hline
\end{tabular}

Table (4) Serum vit D differences according to food borne and air borne

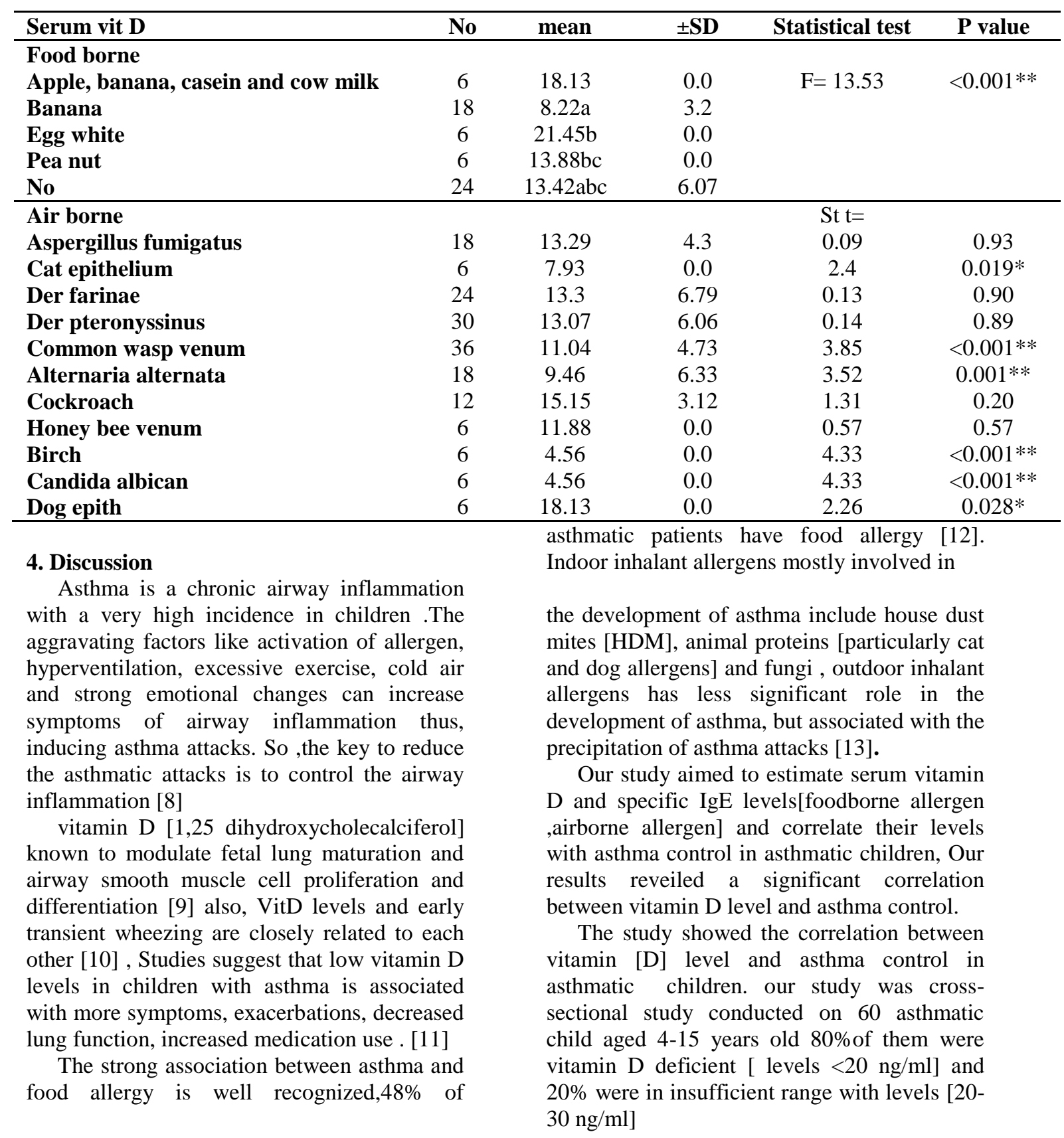


our results showed no significant difference between mean serum vit. [D] regarding age and sex. This in agreement with [14] study conducted on 96 asthmatic children aged 512years showed no significant correlation between age ,sex and Vitamin D, Also [15] study showed no statistically significant differences in age, sex and BMI of the asthmatic children between the high and low 25-[OH]D groups [P>0.05].

In our study there was significant correlation between child Order in his sibling and vitamin [D] level $<0.001$.

This in agreement with [16] study which showed statistically significance between Birth order [1st or $2^{\text {nd }}[173]$ 3rd or $4^{\text {th }}$ [196] $\geq 5^{\text {th }}[114]$.] and vitamin $\mathrm{D}$ level with $\mathrm{P}$ value $<$ 0.003 .

Family history of asthma was found in $60 \%$ of asthmatic children and showed statistically significance with vitamin D level $\mathrm{P}<<\mathbf{0 . 0 0 1}$.

This in agreement with [16] in his study family history of asthma in asthmatic children represent $63.6 \%$ and show significance with Vitamin D level P $<0.009$.

In our study Vitamin D showed a significant correlation regarding Annual vaccination [influenza , pneumococcal vaccine] evidenced by [P $=0.015]$.

This in agreement with [17] study that showed significant correlation between children who received influenza vaccine coupled to Vitamin D compared to children who received the isolated vaccine [ $p=0.001]$.

In our study recurrent exacerbations and hospitalizations increased in those with deficient vitamin D levels, number of hospitalizations/ and frequency of asthma exacerbation per year significantly correlate vitamin D level [p <0.001**, highly significant],

In agreement with our results [15] his results showed that the level of 25-[OH]D was decreased in children with recurrent asthma attack, which is associated with the inflammatory mediators, IL- 6 and TNF- $\alpha$, as well as pulmonary functions $[\mathrm{P}<0.05]$

Our study reveiled statistically significant difference between serum vitamin D level and associated atopic conditions.

This in agreement with [18] prospective study determined that vitamin D insufficiency increased the risk of atopy and asthma development.

Our study revealed no significant difference in mean serum vit. [D] according to passive smoking

In agreement with our results [19] found that Children with both non-smoking parents presented significantly higher serum levels of $25[\mathrm{OH}] \mathrm{D}$ than children with both smoking parents.

Our results showed statistically significant difference between vitamin D level and degree of interference of activity $[\mathrm{p}<\mathbf{0 . 0 1 6}]$.

This in agreement with [16] case control study found that asthmatic children with vitamin D defficiency $[p<0.001]$ showed less physical activity

A significant inverse association was observed between vitamin D levels and severity of asthma [p<0.001**]. $20 \%$ of cases with MILD asthma had insufficient vitamin D levels as compared to $80 \%$ cases with moderate/severe asthma with vitamin D deficiency.

In agreement with our results [20], [21],[14] found a significant correlation between vitamin $D$ levels in asthmatic children and asthma severity [p $<, 001]$ study ,

Levels of asthma control in our study were classified as good control, fair control and poor control as GINA guidelines [22]Significant [p $=0.001]$ inverse correlation was found between vitamin D levels and level of asthma control, $40 \%$ of children with deficient levels of vitamin $\mathrm{D}$ were associated with poor asthma control.

This in agreement with [14],[23],[24] and15 study which showed statistically significant correlation between asthma control and vitamin D status [p value $<0.001$ ]

Our study showed $60 \%$ of asthmatic childern had food allergy $30 \%$ of them were allergic to banana, $10 \%$ to egg white, $10 \%$ to peanut and $10 \%$ o were multiple food allergy to [banana, apple,casein and cow milk] .

This go in hand with [25] showed significant results in food-specific serum $\operatorname{IgE}$ measured to peanut, cow's milk, egg white, and shrim higher in asthmatic children associated with vitamin $\mathrm{D}$ deficiency.

our study showed that asthma in children associated with increase specific IgE of airborn allergen [Asperigillus fumigates and altrnaria alternata constituted $30 \%$ of the studied group ,Der.farinae $40 \%$, Der. pteronyssinus $50 \%, 60 \%$ common wasp venom and cockroach $20 \%$. Honey bee venum ,Birch ,Candida albican ,Dog epith and Cat epithelium represented $10 \%$ for each ].

In agreement with our results [7] found Sensitivity to outdoor pollens not associated with Vitamin [D] levels, Mold allergens cat aeroallergen and Alternaria species in particular showed a trend toward lower VitD levels that did not achieve significance. However, sensitivity to the indoor aeroallergens $\operatorname{dog}[\mathrm{P}=.045]$ and house dust 
mite $[\mathrm{P}=, 05]$ were significantly associated with lower Vitamin [D] levels.

[26] reprted that Vitamin D levels in asthmatic children were also significantly associated with reductions in levels of $\operatorname{IgE}$ to dust mite There was no significant association between vitamin $\mathrm{D}$ levels and serum $\operatorname{IgE}$ to cockroach.

\section{Conclusion}

This study concluded that, Deficient vitamin [D] associated with poor asthma control in asthmatic children. Targeting that vitamin [D] was positively and significantly associated with asthma control.

\section{References}

[1] Y.X. Zhang, Y.Liu, Y.Xue, L.Y.Yang, Song GD and Zhao L: Correlational study on atmospheric concentrations of fine particulate matter and children cough variant asthma. Eur Rev Med Pharmacol Sci. ,Vol.20,PP.2650-2654,2016.

[2] G.Q.Yin, W.H.Jiang, P.Q.Wu, C.H.He, Chen RS and Deng L: Clinical evaluation of sublingual administration of dust mite drops in the treatment of allergic asthma and allergic rhinitis of children. Eur Rev Med Pharmacol Sci. ,Vol.20,PP.43484353,2016.

[3] M.Hoxha, M.Zoto, L.Deda and G.Vyshka,Vitamin D and its role as a protective factor in allergy. Int Sch Res Notices 951946,Vol.3,PP.25-31,2014.

[4] C.A.Camargo, D.Ganmaa, A.L.Frazier, Randomized trial of vitamin D supplementation and risk of acute respiratory infection in Mongolia. Paediatrics, Vol.130(2), PP.561567,2012.

[5] D.Proud, Role of rhinovirus infection in asthma. Asian Pac J Allergy Immunol,Vol.29,PP.201-208,2011.

[6] S.Asilsoy, Vitamin D and allergic diseases. Asthma Allergy.,Vol.7(2), PP.6269,2011.

[7] D.A .Searing, Y. Zhang, J.R.Murphy, P.J.Hauk, E. Goleva, Decreased serum vitamin D levels in children with asthma are associated with increased corticosteroid use. J Allergy Clin Immunol ,Vol.125(5), PP.9951000,2010.

[8] R.Agarwal, S. Dhooria , A.Aggarwal, V.Maturu, I. Sehgal, V.Muthu, , D. Behera, Guidelines for diagnosis and management of bronchial asthma: Joint ICS / NCCP [I] recommendations. Lung India, Vol.32(7),

PP.4103/09702113,2015.
[9] M.Yurt, J.Liu, R.Sakurai, M.Gong, S.M.Husain, M.A .Siddiqui, Vitamin D supplementation blocks pulmonary structural and functional changes in a Rat model of perinatal vitamin D deficiency. Am J Physiol Lung Cell Mol Physiol,Vol.307,PP.59-67,2014.

[10] H.Einisman, M.L.Reyes, J.Angulo, J.Cerda, M. López-Lastra, J.A.CastroRodriguez, Vitamin D levels and vitamin $\mathrm{D}$ receptor gene polymorphisms in asthmatic children: A case-control study. Pediatr Allergy Immunol,Vol.26,PP.545$550,2015$.

[11] K.M.Kunisaki, D.E.Niewoehner, J.E.Connett, COPD Clinical Research Network. Vitamin D levels and risk of acute exacerbations of chronic obstructive pulmonary disease: a prospective cohort study. Am J Respir Crit Care Med,Vol.185(3), PP.286- 290, 2012.

[12] G. Roberts, N. Patel, F. Levi-Schaffer, P. Habibi, G. Lack, Food allergy as a risk factor for life-threatening asthma in childhood: A case-controlled study. J. Allergy Clin. Immunol, Vol.112, PP.168174,2003.

[13] B.Erbas, M. Akram, S.C.Dharmage, The role of seasonal grass pollen on childhood asthma emergency department presentations. Clin Exp Allergy,Vol.42(5), PP.799-805,2012.

[14] E. Krishnan, V .Ponnusamy, S.P. Sekar Int $\mathbf{J}$ Res Med Sci, Trial of vitamin D supplementation to prevent asthma exacerbation in children Int $\mathbf{J}$ Res Med Sci. Vol.5(6), PP.2734-2740,2017

[15] S.Wang, Y. Pan, \& Z. Zhang, Relationship between 25-hydroxyvitamin D levels and inflammatory factors in children with asthma attack. Experimental and Therapeutic Medicine,Vol.1(3), PP.45-52,2018.

[16] A. Bener, M. S. Ehlayel, M. K. Tulic, \& Q. Hamid, Vitamin D Deficiency as a Strong Predictor of Asthma in Children. International Archives of Allergy and Immunology, Vol.157(2), PP.168$175,2012$.

[17] C. Tayeh, P. Noun, A. Farah, Y. Khalife, G. Abi Fares, M.Amm, H.Feghali, G .Nicolas, and M.C. Fadous Khalife, Flu Vaccine Coupled to Vitamin D Decrease the Frequency of Lower Respiratory Tract Infections [Randomized Controlled Trial]. Open Journal of Pediatrics, Vol.7,PP.353-358,2017.

[18] E.M.Hollams, P.H.Hart, B.J.Holt, M.Serralha, F.Parsons, NH.de Klerk, 
G.Zhang, PD.Sly, P.G.Holt, Vitamin D and atopy and asthma phenotypes in children: a longitudinal cohort study. Eur Respir J,Vol.38,PP.1320-1327,2011.

[19] I.Chinellato, M.Piazza, M.Sandri, G.Paiola, G.Tezza, \& A. L. Boner, Correlation between vitamin D serum levels and passive smoking exposure in children with asthma. In Allergy \& Asthma Proceedings ,Vol.37,PP.136670,2018.

[20] H.G. Elnady, E.M.Fouda, O.M. Elsheikh, R. Inas, Serum vitamin D level as a predictor of bronchial asthma in Egyptian children. Journal of the Arab Society for Medical research, Vol. 3,PP.67-78,2013.

[21] M.F. Afifi, M. El-Hosseiny, A.M .Othman, Serum Levels of Vitamin D in Children with Bronchial Asthma MJMR,Vol. 9,PP.77-67,2014.

[22] Global Initiative for Asthma: Definition, description, and diagnosis of asthma Available from http://ginasthma. org/ gina- reports/. Vol.2(3), PP.55-65,2018.

[23] A. Gupta, A .Sjoukes, D. Richards, W. Banya, Hawrylowicz C Relationship between serum Vitamin D, disease severity, and airway remodelling in children with asthma. Am J Respir Crit Care Med,Vol.184(12),PP.1342-9. 2011.

[24] S. Awasthi and K. Vikram,Serum 05 Hydroxy Vitamin D Insufficiency Associated with Bronchial Asthma in Lucknow, India.Indian J Pediatr, Vol.38,pp82-88,2014.

[25] A.H.Liu, R. Jaramillo, S.H.Sicherer, R.A. Wood, S.A.Bock, A.W. Burks, M. Massing, R.D.Cohn, D.C. Zeldin, National prevalence and risk factors for food allergy and relationship to asthma: Results from the National Health and Nutrition Examination Survey 20052006. J. Allergy Clin. Immunol,Vol.126, PP.798-806,2010.

[26] J. M. Brehm, J. C.Celedón, M. E. SotoQuiros, L. Avila, G. M. Hunninghake, E.Forno, Litonjua, A. A. Serum, Vitamin D Levels and Markers of Severity of Childhood Asthma in Costa Rica. American Journal of Respiratory and Critical Care Medicine, Vol.179(9),PP.765-771,2009. 